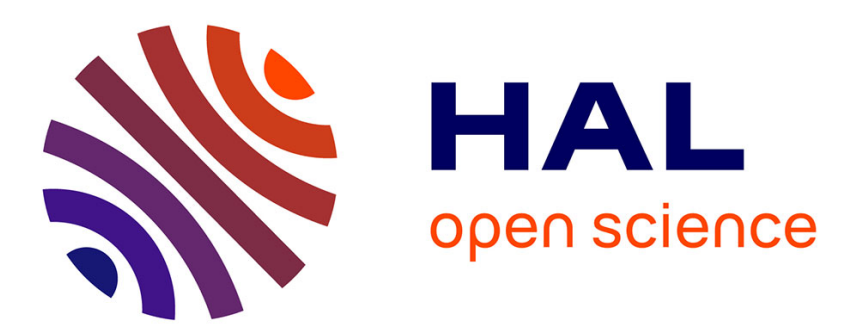

\title{
AES and ToF-SIMS combination for single cell chemical imaging of gold nanoparticle-labeled Escherichia coli
}

Cecile Courreges, Delphine Flahaut, Mélanie Bonnecaze, Sophie Nolivos, Regis. Grimaud, Joachim Allouche

\section{- To cite this version:}

Cecile Courreges, Delphine Flahaut, Mélanie Bonnecaze, Sophie Nolivos, Regis. Grimaud, et al.. AES and ToF-SIMS combination for single cell chemical imaging of gold nanoparticle-labeled Escherichia coli. Chemical Communications, 2021, 57 (44), pp.5446-5449. 10.1039/d1cc01211h . hal-03265407

\section{HAL Id: hal-03265407 https: / hal-univ-pau.archives-ouvertes.fr/hal-03265407}

Submitted on 5 Oct 2021

HAL is a multi-disciplinary open access archive for the deposit and dissemination of scientific research documents, whether they are published or not. The documents may come from teaching and research institutions in France or abroad, or from public or private research centers.
L'archive ouverte pluridisciplinaire HAL, est destinée au dépôt et à la diffusion de documents scientifiques de niveau recherche, publiés ou non, émanant des établissements d'enseignement et de recherche français ou étrangers, des laboratoires publics ou privés. 


\title{
AES and ToF-SIMS combination for single cell chemical imaging of gold nanoparticle-labeled Escherichia coli.
}

Received 00th January 20xx,

\author{
Cécile Courrèges ${ }^{\mathrm{a}}$, Mélanie Bonnecaze ${ }^{\mathrm{a}}$, Delphine Flahaut ${ }^{\mathrm{a}}$, Sophie Nolivos ${ }^{\mathrm{b}}$, Régis Grimaud ${ }^{\mathrm{b}}$ and \\ Joachim Allouche $\mathrm{a}^{*}$
}

\begin{abstract}
A chemical fingerprint of Escherichia coli cells surface labeled by gelatin coated gold nanoparticles was obtained by combining Auger Electron Spectroscopy (AES) for single cell level chemical images, and Time-of-Flight Secondary Ion Mass Spectroscopy (ToF-SIMS) Tandem MS for unambiguous molecular identification of co-localized species.
\end{abstract}

In order to fully apprehend complex biological processes occurring at a multicellular level as well as at the ecosystems level, investigating molecular mechanisms occurring in a single cell is essential. ${ }^{1}$ This is crucial for answering to a wide range of biological issues related to fundamental biology as well as pathological processes. $^{2}$ Single cell imaging provides morphological, chemical and physical characterizations at a length scale from microns to nanometers. ${ }^{3}$ Particularly, single cell chemical imaging is still challenging as it presents a dual constraint consisting in (i) an elemental, isotopical or molecular detection with (ii) a chemical localization at a nanometer scaled lateral resolution. This is especially the case for bacteria due to their smaller sizes $(\approx 1 \mu \mathrm{m})$ compared to eukaryotic cells. Only a few techniques capable of meeting those requirements are currently available. For instance, super-resolved optical techniques have benefited in the past recent years from technical advances allowing to reach nanoscaled resolution. ${ }^{4,5}$ Different approaches based on fluorescent tags, 4,6 pump-probe process $^{7}$ or coherent scattering ${ }^{8}$ have been developed using optical algorithms or mathematical signal treatment ${ }^{3}$ to extend the boundaries of the optical microscopy Abbe's diffraction resolution limit. ${ }^{9}$ However, few of them allowed chemical, elemental or molecular multi-detection excepting for instance plasmonic based optical spectroscopy like Surface Enhanced Raman Spectroscopy (SERS). ${ }^{10}$ This technique has recently given chemical spatial resolution near those of scanning electron

a. Université de Pau et des Pays de l'Adour, E2S UPPA, CNRS, Institut des Sciences Analytiques et Physico-chimie pour l'environnement et les matériaux (IPREM), 2 avenue du Président Angot, 64000 Pau, France.

b. Université de Pau et des Pays de l'Adour, E2S UPPA, CNRS, Institut des Sciences Analytiques et Physico-chimie pour l'environnement et les matériaux (IPREM), avenue de l'université, 64000 Pau, France.

* corresponding author

‡Electronic Supplementary Information (ESI) available: [details of any supplementary information available should be included here]. See DOI: $10.1039 / x 0 \times x 00000 x$ microscopy (SEM) by exploiting the plasmon resonance of metallic nanostructures. ${ }^{3,11}$ Concerning non optical imaging techniques, transmission electron microscopy (TEM) combined to energy dispersive spectroscopy (EDS) or electron loss energy spectroscopy $(E E L S)^{12,13}$ still provide high resolved chemical images $(<10 \mathrm{~nm})$ but require time consuming and complex sample preparation based on resin inclusions and ultramicrotome cutting. Another example is X-ray fluorescence (XRF) nanotomography that has been performed recently using hard X-ray with a sub-15 $\mathrm{nm}$ nanoprobe beamline to image the elemental distribution in E. coli at nanoscale. ${ }^{14}$ Secondary ion mass spectrometry (SIMS) have also been performed successfully to image single cells. ${ }^{15,16}$ Nano-SIMS is for instance one of the best resolved techniques to image elemental and

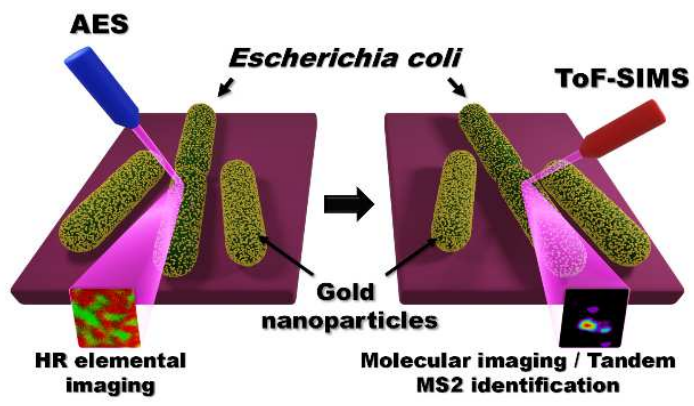

Scheme 1 Combination of ToF-SIMS and AES chemical surface analyses of $E$. coli modified by gold nanoparticles tags.

isotopic distributions at the single cell level with lateral resolution close to $50 \mathrm{~nm} .{ }^{17}$

ToF-SIMS has yet been performed in combination to other techniques to image materials ${ }^{18}$ as well as single cells including bacteria with submicron lateral resolution. ${ }^{19-22}$ However, unambiguous peak assignment of the fragments coming from high molecular weight cell surface species is still challenging on bacteria. AES is a surface sensitive technique based on the detection of the short escape depth Auger electrons (in the 0.3 to $5 \mathrm{~nm}$ range). ${ }^{23,24}$ This technique, widely used to perform chemical imaging at a high lateral resolution (up to $10 \mathrm{~nm}$ ) of materials, ${ }^{25,26}$ has never been used previously to characterize the surface of bacteria at a single cell level. In this paper, we propose a novel approach (scheme 1) based on the ex situ combination of AES and ToF-SIMS equipped with a Tandem MS analyzer ${ }^{27,28}$ to image the surface of bacteria at a single cell 
level. To our knowledge, this is the first use of AES for elemental mapping of bacteria at a single cell level. In contrary to other techniques, our method provides a unique chemical fingerprint of cell surface through the complementary of molecular and elemental detections at nanoscale. Gelatin coated gold nanoparticles have been used to tag cells and enhance the chemical signals detection.

In a first step, ToF-SIMS mass spectra (figure 1) were acquired, using the same analysis conditions in negative polarity, for E. coli cells (top line), E. coli cells incubated with gelatin-coated gold nanoparticles (middle line) and gelatincoated gold nanoparticles (bottom line).
In a second step, $2 \mathrm{D}$ spatial distributions of $\mathrm{CN}^{-}, \mathrm{PO}_{2}^{-} \mathrm{CNAu}_{2}^{-}$and $\mathrm{Au}_{3}{ }^{-}$molecular fragments were obtained by ToF-SIMS chemical imaging (figure 2) for cells interacting with nanoparticles (top line) and cells alone (bottom line) over $25 \mu \mathrm{m} \times 25 \mu \mathrm{m}$ field of view. The co-localization of all signals for bacteria with gold nanoparticles, proves the interactions between these two species; indeed the signal of phosphate groups characteristics of bacteria outer membrane phospholipids is detected at the same area as $\mathrm{CNAu}_{2}{ }^{-}$and $\mathrm{Au}_{3}{ }^{-}$signals, specific of gelatin coatedgold nanoparticles. Due to opposite global charges (negative for bacteria and positive for nanoparticles), it is more than likely that these entities are attracted by each other through

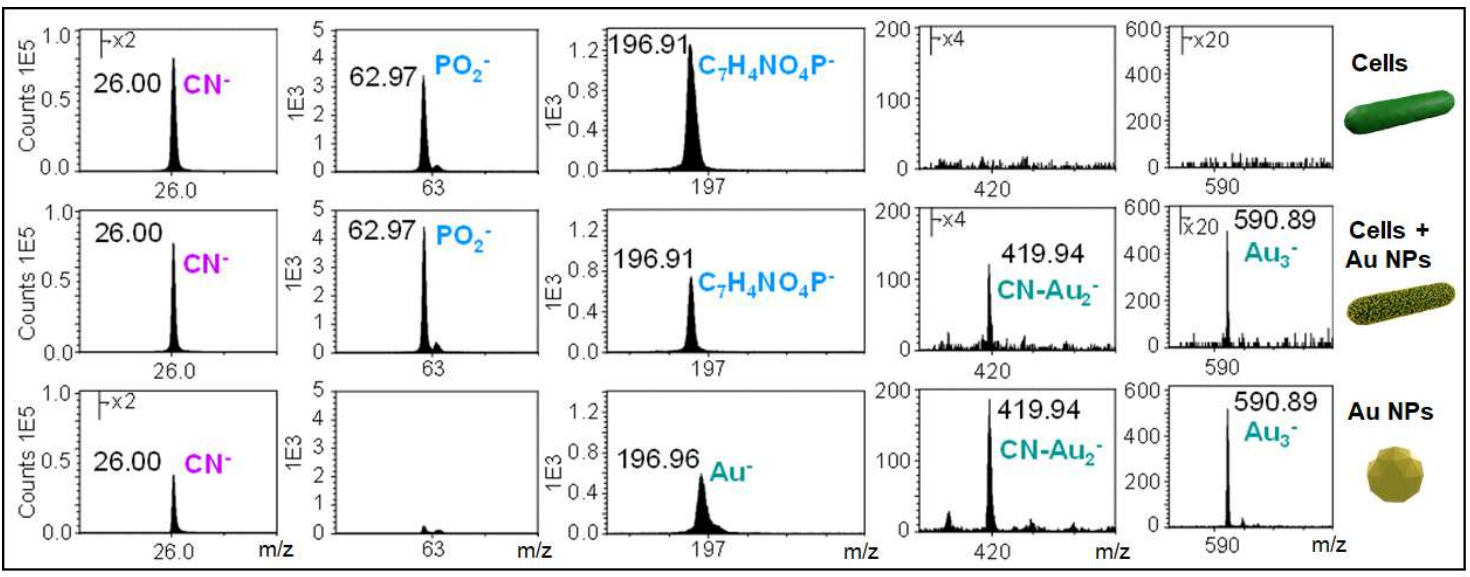

Figure 1. Negative ToF-SIMS mass spectra over $\mathrm{CN}^{-}(\mathrm{m} / \mathrm{z} 26.00), \mathrm{PO}_{2}^{-}(\mathrm{m} / \mathrm{z} 62.97), \mathrm{Au}^{-}\left(\mathrm{m} / \mathrm{z}\right.$ 196.96), $\mathrm{CN}-\mathrm{Au}_{2}^{-}{ }^{-}(\mathrm{m} / \mathrm{z} 419.94)$ and Au $3^{-}(\mathrm{m} / \mathrm{z} 590.89) \mathrm{m} / \mathrm{z}$ ranges of E. coli cells (top line), E. coli cells incubated with gelatin-coated gold nanoparticles (middle line) and gelatin-coated gold nanoparticles (bottom line); Intensity scale expenders are indicated when necessary.

$m / z$ ranges specific of $\mathrm{CN}^{-}(\mathrm{m} / \mathrm{z} 26.00), \mathrm{PO}_{2^{-}}(\mathrm{m} / \mathrm{z} 62.97), \mathrm{Au}^{-}$ (m/z 196.96), $\mathrm{CN}^{-\mathrm{Au}_{2}-}\left(\mathrm{m} / \mathrm{z}\right.$ 419.94) and $\mathrm{Au}_{3}^{-}(\mathrm{m} / \mathrm{z}$ 590.89) molecular fragments, are presented for each system. $\mathrm{CN}^{-}$ fragment is most likely to come from bacteria outer membrane molecules (like phospholipids and lipopolysaccharides) and gelatin coated on gold nanoparticles. For cells with gold nanoparticles, the two signals are overlaid which is consistent with a higher intensity signal. Phosphate groups $\left(\mathrm{PO}_{2}^{-}\right)$originate from bacteria outer membrane phospholipids and are only observed for cells alone and cells with gold nanoparticles.

Tandem MS was used to confirm the assignment of $\mathrm{m} / \mathrm{z} 419.94$ and $m / z 590.89$ peaks to $\mathrm{CNAu}_{2}{ }^{-}$and $\mathrm{Au}_{3}{ }^{-}$respectively (figure $\mathrm{S} 3$ ESI ), which are molecular fragments specific of gold nanoparticles alone or in interaction with cells. More interestingly, Au- signal ( $m / z$ 196.96) is only detected for gold nanoparticles without bacteria; indeed, the signal observed at $\mathrm{m} / z 196.91$ for cells alone and in interaction with nanoparticles is attributed to $\mathrm{C}_{7} \mathrm{H}_{4} \mathrm{NO}_{4} \mathrm{P}^{-}$molecular fragment, which is characteristic of cells outer membrane phospholipids. The same observation was done in positive polarity (figure S4 ESI ), where specific peaks of the phosphatidylcholine head group of bacteria membrane phospholipids are detected for $E$. coli cells interacted with gold nanoparticles, but no peaks characteristics of gold. Such result can be explained either by a change of the gold fragmentation pattern when nanoparticles interact with cells or by a higher ionization yield of organic species that hide elemental gold signal. ${ }^{29}$ electrostatic forces. For cells alone, only $\mathrm{CN}^{-}$and $\mathrm{PO}_{2}$ - signals are observed with a much lower intensity compared to the one of cells with nanoparticles; in the last case, the signal

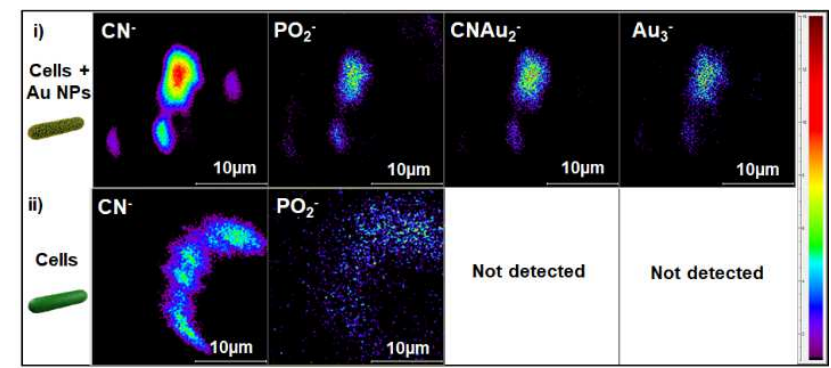

Figure 2. ToF-SIMS 2D chemical mappings of i) $\mathrm{CN}^{-}\left(\mathrm{m} / z\right.$ 26.00), $\mathrm{PO}_{2}^{-}(\mathrm{m} / z$ 62.97), $\mathrm{CNAu}_{2}{ }^{-}\left(\mathrm{m} / z\right.$ 419.94) and $\mathrm{Au}_{3}{ }^{-}(\mathrm{m} / z$ 590.89) molecular fragments of $E$. coli cells incubated with gelatin-coated gold nanoparticles and ii) $\mathrm{CN}^{-}(\mathrm{m} / \mathrm{z} 26.00), \mathrm{PO}_{2}^{-}(\mathrm{m} / \mathrm{z}$ 62.97) of single E.coli cells, over $25 \mu \mathrm{m} \times 25 \mu \mathrm{m}$ field of view (the color scale is indicated on the side: red represents the highest intensity and purple the lowest one).

enhancement, especially noticeable for $\mathrm{CN}$-, may be attributed to the presence of gold metal, which improves the ionization yield of species nearby. ${ }^{30,31}$ 
To go further on the bacteria characterization at nanoscale, AES was performed. Firstly, E. coli without gold nanoparticles used as control sample were deposited on silica wafers and characterized by AES. Figure 3a displays a SEM image of a single cell with 4 target analyses dots corresponding to the Auger spectra obtained on Figure 3b. For dot 1, 2 and 3, the P LVV (100 eV-125 eV), C KLL (220 eV-280 eV), N KLL (349 eV-395 eV) and O
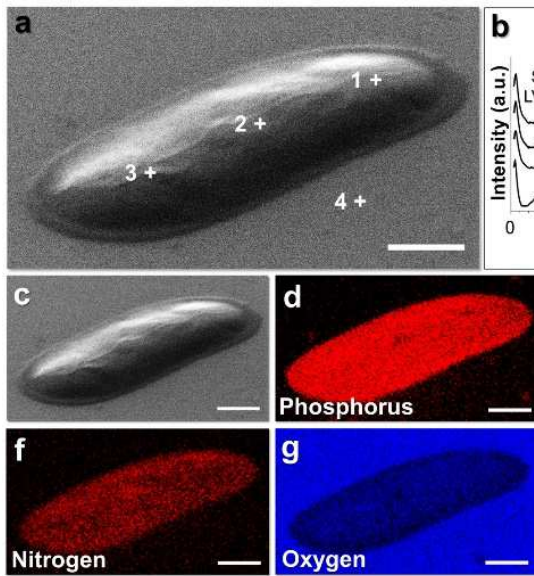

Figure 3. AES characterization of a single $E$. coli. (a) SEM image with target dots and (b) the corresponding AES spectra, (c) SEM image and the corresponding SAM elemental maps of (d) Phosphorus, (e) Carbon, (f) Nitrogen, (g) Oxygen and (h) $\mathrm{P}+\mathrm{C}+\mathrm{O}$ overlay signals (scale bar $=400 \mathrm{~nm}$ ).

KLL (465 eV-520 eV) Auger transitions attest of a good detection of the cell outer membrane molecules: proteins, lipopolysaccharides (LPS) and phospholipids (PL). Due to the well-known contribution of the backscattered electron (BSE) diffusion to the Auger signal, a Si LVV transition (40 eV- $95 \mathrm{eV}$ ) corresponding to the adhesion substratum was also observed. For comparison, the dot 4 spectrum corresponding to the substratum analysis exhibits an intense Si peak but no nitrogen and phosphorus signals coming from BSE contribution. This is due to the density of $\mathrm{SiO}_{2}$ that lower the excitation volume in comparison to dots 1 to $3 .{ }^{23,24}$ On the other hand, elemental Scanning Auger Maps (SAM) of phosphorus, carbon, nitrogen and oxygen are displayed on Figure $3 \mathrm{~d}, \mathrm{e}, \mathrm{f}$ and $\mathrm{g}$. Figure $3 \mathrm{c}$ and Figure $3 \mathrm{~h}$ correspond to the SEM image and to the $\mathrm{P}+\mathrm{C}+\mathrm{O}$ signals overlay respectively. It is worth noting that the SAM pictures match the SEM image shown on Figure 3c perfectly, indicating the good lateral resolution of AES for the elemental imaging of single cells.

$30 \pm 10 \mathrm{~nm}$ gelatin coated gold nanoparticles (see ESI¥ for XPS characterization and figure S1 for TEM pictures) were bound on the bacteria surface due to electrostatic interactions between positive and negative charge of gold nanoparticles and $E$. coli membrane surface respectively. On Figure $4 a$, one dividing $E$. coli cell has been decorated by gold nanoparticles and two analysis target dots have been selected. The corresponding AES spectra of these target dots displayed on Figure $4 \mathrm{~b}$ show $\mathrm{C}, \mathrm{O}$, and $\mathrm{N}$ transitions as for control samples and Si KLL (1450 eV$1630 \mathrm{eV}$ ) transition corresponding to the BSE contribution substrate signal as mentioned above.

Au MNN (1625 eV- $2125 \mathrm{eV}$ ) transition was also detected for dot 1 which match the gold nanoparticles bound on cells. The spectrum of dot 2 focusing bacteria membrane (without gold
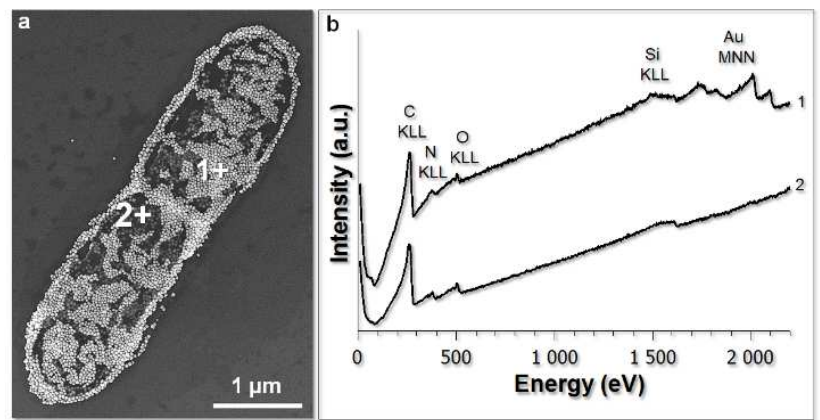

Figure 4. AES spectra analyses of $E$. coli cells decorated by gelatin coated gold nanoparticles. (a) SEM image of cells with the target dots and (b) the corresponding AES dot 1 and dot 2 spectra focusing gold nanoparticles on cell membrane and gold-free cell membrane respectively.

nanoparticles) does not exhibit detectable $\mathrm{Au}$ transition attesting of the good surface sensitivity and high lateral selectivity by the AES probe.

High resolution SAM elemental mapping has been performed on one other dividing cell (SEM on Figure 5a). The mapping has been carried out by focusing the scanning analysis area within the red dotted line square using high magnification operating conditions. SEM image is depicted on Figure $5 \mathrm{~b}$ whereas the Figures $5 \mathrm{c}$ to $5 \mathrm{~g}$ display the elemental maps of carbon, gold, nitrogen, oxygen and carbon + gold overlay respectively. The latter exhibits a very good correspondence of the $\mathrm{Au}$ (gold nanoparticles) and C (cell membrane) Auger signals with the SEM image (figure S6 ESI¥ for lower magnification maps). The chemical lateral resolution has been estimated successfully to $30 \mathrm{~nm}$ using an AES line profile image (scanning mode, figure S5 ESI‡) performed on $\mathrm{C}$ and Au signals detected along a line on the cell surface. To our knowledge, these results has never been obtained elsewhere previously on bacteria using AES. This

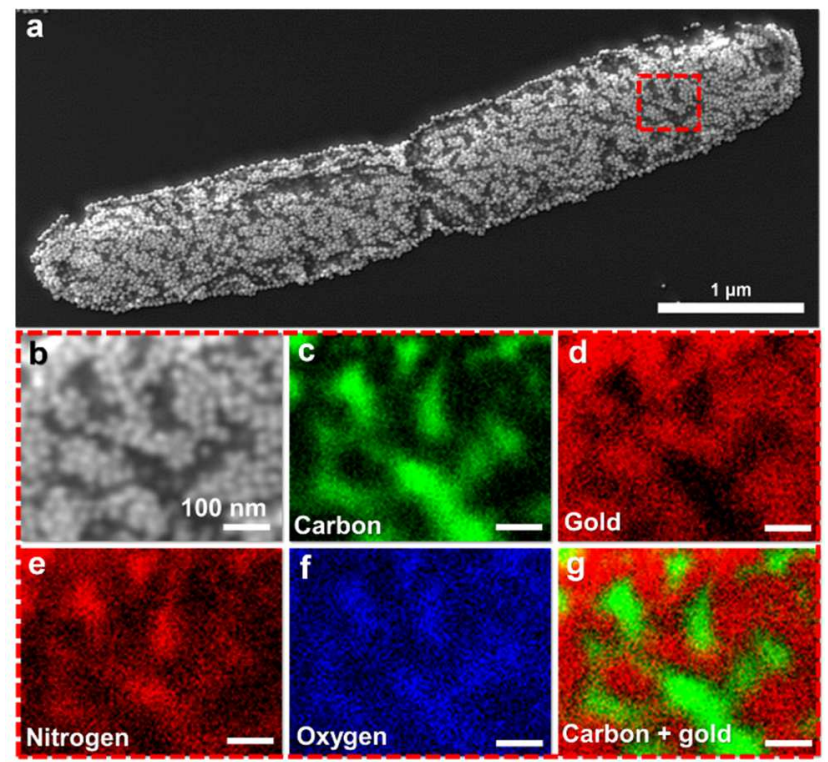

Figure 5. High resolution SAM elemental maps of gold nanoparticles coated E. coli. (a) SEM images of cells showing the analyzed area (red square) used for the elemental maps. (b) SEM image and related SAM elemental maps of (c) Carbon, (d) Gold, (e) Nitrogen, (f) Oxygen and (g) Carbon + Gold overlay signals. 
spatial chemical resolution is in the range of the best resolved chemical characterization techniques.

Such results confirm the power of the ToF-SIMS Tandem MS technique to image $E$. coli with unambiguous molecular identification of species coming specifically from nanoparticles and bacteria in interaction. ToF-SIMS provides molecular information whereas AES, used for the first time on bacteria, gives elemental distribution data at nanoscale, supporting the good complementarity of the two techniques. This approach highlights the possible identification of a unique and enhanced chemical fingerprint of bacteria surface opening the way to new strategies for the study of pathogen outer membrane or characterization of biomarkers on cells surface.

We would like to thanks Arkema for TEM analyses of gold nanoparticles and CNRS, UPPA-E2S and Aquitaine region for their financial support.

\section{Conflicts of interest}

There are no conflicts to declare.

\section{Notes and references}

1 A. Belianinov, A. V. levlev, M. Lorenz, N. Borodinov, B. Doughty, S. V. Kalinin, F. M. Fernández and O. S. Ovchinnikova, ACS Nano, 2018, 12, 11798.

2 C. Petibois, Anal. Bioanal. Chem., 2010, 397, 2051.

3 A. P. Olson, K. B. Spies, A. C. Browning, P. A. G. Soneral and N. C. Lindquist, Sci. Rep., 2017, 7:9135, 1.

4 J. Xiao and Y. F. Dufrêne, Nat. Microbiol., 2016, 1, 1.

5 S. Yue, X. Song, W. Song and S. Bi, Chem. Sci., 2019, 10, 1651.

6 K. Wicker and R. Heintzmann, Nat. Photonics, 2014, 8, 342.

7 P. Wang, M. N. Slipchenko, J. Mitchell, C. Yang, E. O. Potma, X. Xu and J.-X. Cheng, Nat. Photonics, 2013, 7, 449.

8 F. Jünger, P. v Olshausen and A. Rohrbach, Sci. Rep., 2016, 6, 1.

9 M. G. L. Gustafsson, J. Microsc., 2000, 198, 82.

10 E. H. Hill and L. M. Liz-Marzán, Curr. Opin. Colloid Interface Sci., 2017, 32, 1.

11 M. Bocková, J. Slabý, T. Špringer and J. Homola, Annu. Rev. Anal. Chem., 2019, 12, 151.

12 Mengke-Li, Yuting-Zhuo, Yuting-Hu, Shuzhen-Li, Liang-Hu, HuiZhong, and Zhiguo-He, Ecotoxicol. Environ. Saf., 2019, 184, 109636.

13 C. P. Lechene, Y. Luyten, G. McMahon and D. L. Distel, Science, 2007, 317, 1563.

14 T. W. Victor, L. M. Easthon, M. Ge, K. H. O'Toole, R. J. Smith, X. Huang, H. Yan, K. N. Allen, Y. S. Chu and L. M. Miller, Sci. Rep., 2018, 8, 1.

15 L. Yin, Z. Zhang, Y. Liu, Y. Gao and J. Gu, Analyst, 2019, 144, 824.

16 I. S. Gilmore, S. Heiles and C. L. Pieterse, Annu. Rev. Anal. Chem., 2019, 12, 201.

17 J. Nuñez, R. Renslow, J. B. Cliff and C. R. Anderton, Biointerphases, 2017, 13, 03B301.

18 Z. Li, X. Tan, P. Li, P. Kalisvaart, M. T. Janish, W. M. Mook, E. J. Luber, K. L. Jungjohann, C. B. Carter and D. Mitlin, Nano Lett., 2015, 15, 6339.

19 S. Vaidyanathan, J. S. Fletcher, R. Goodacre, N. P. Lockyer, J. Micklefield and J. C. Vickerman, Anal. Chem., 2008, 80, 1942.
$20 \mathrm{H}$. Tian, D. A. Six, T. Krucker, J. A. Leeds and N. Winograd, Anal. Chem., 2017, 89, 5050.

21 S. Yoon and T. G. Lee, Nano Converg., 2018, 5:24, 1.

22 P. Massonnet and R. M. A. Heeren, J. Anal. At. Spectrom., 2019, 34, 2217.

23 J. Cazaux, Surf. Interface Anal., 1989, 14, 354.

24 W. E. S. Unger, T. Wirth and V.-D. Hodoroaba, in Characterization of Nanoparticles, Elsevier, 2020, pp. 373-395.

25 J. B. Ledeuil, A. Uhart, S. Soulé, J. Allouche, J. C. Dupin and H. Martinez, Nanoscale, 2014, 6, 11130.

26 P. M. P. Danty, A. Mazel, B. Cormary, M. L. D. Marco, J. Allouche, D. Flahaut, J. Jimenez-Lamana, S. Lacomme, M.-H. Delville and G. L. Drisko, Inorg. Chem., 2020, 59, 6232.

27 J. S. Fletcher, Biointerphases, 2015, 10, 018902.

28 G. L. Fisher, A. L. Bruinen, N. Ogrinc Potočnik, J. S. Hammond, S. R. Bryan, P. E. Larson and R. M. A. Heeren, Anal. Chem., 2016, 88, 6433.

29 S. J. B. Dunham, T. J. Comi, K. Ko, B. Li, N. F. Baig, N. Morales-Soto, J. D. Shrout, P. W. Bohn and J. V. Sweedler, Biointerphases, 2016, 11, 02 A325.

30 A. S. Mohammadi, J. S. Fletcher, P. Malmberg and A. G. Ewing, Surf. Interface Anal., 2014, 46, 379.

31 H.-W. Li, X. Hua and Y.-T. Long, Chin. J. Anal. Chem., 2018, 46, 61. 